\title{
Identity in a World of Scarcity: The Book of Eli
}

\author{
José Murício Saldanha-Álvarez \\ Fluminense Federal University, Niteroi, Brazil
}

\begin{abstract}
This paper examines the construction of identity in Hugue's brothers movie, The Book of Eli setting in an America post-apocalyptic world destroyed by nuclear war and environmental disasters. Economic relations in this world without time or history and without production of goods and commodities, are based on ancient practices such as barter. The goods are exchanged for goods according to the need and the currency lost its meaning before the supreme usefulness. Essential items to human life like water now have a very high value due to its complete scarcity. Eli (played by Denzel Washington) toured the United States for 30 years westward circling the wasteland leading the only existing copy of the King James version of the Bible. Then he reaches the town, which is under the control of Carnegie, the villain, whose ambition is to have the holy Bible in order to exercise power. In this world full of shortages, power belongs to the old that has the memory of the past. Texts of Giddens, Beck, Lash, Benveniste, and Marx compose the theoretical apparatus that allow understanding how to reconstruct the identity in a world in crisis, and no shortage of complete story without memory card with the movement of goods excluding currency.
\end{abstract}

Keywords: identity, history, memory, Bible, Barths, Narration

\section{Introduction}

The research reported here analyzes the film The Book of Eli (Hugues, Albert \& Hugues, Allen, 2010), set in the post-apocalyptic world destroyed by nuclear war, launched on February 10th, 2010. Directed by the brothers Albert Hughes and Allen Hughes and produced by Sony Pictures, it depicts the survivors living in a devastated America. In the first place, films of this sort become inspiring inasmuch as they bring up the debate about the risks prevailing in international relations shaken by crises, such as the Middle East turmoil. This region today is at a high risk of an outbreak of nuclear war. It can be caused by countries or parties, whose views become crazed by the presence of religious elements. For a Christian as analyst Mark Hitchcock (2012), the world seems increasingly fast, moving as a complex machine while out of control. For the Marxist analysis of Amim (2011), capitalism as a world-system engendered an ethos of accumulation by dispossession. The center-periphery polarization covers the impoverishment and hunger in such a gigantic scale as Karl Marx never predicted. Secondly, The Book of Eli marks the underlying horror of the consequences arising from the perspective of a global environmental catastrophe as the large natural destruction recorded in the last decade. Among other evidence of climate change that is already affecting many countries, people have the problem of freshwater scarcity. In many rich and the BRICS countries, like Brazil, people are already experiencing a

José Murício Saldanha-Álvarez, Ph.D., professor, Universidade Federal Fluminense, Niterói, RJ, Brasil.

Correspondence concerning this article should be addressed to José Murício Saldanha-Álvarez, Rua Le Corbusier, Condominiun Ubá-Pendotiba, C. 65, Matapaca, Niterói, RJ, 24322140, Brazil. E-mail: saldanhaalvarez@hotmail.com. 
serious crisis, which in the near future will reduce the water supply (Bakker, 2010).

Thirdly, Chew (2008) demonstrated that large-scale environmental disasters historically lead to the rupture of the social tissue and cultural factors. This state of affairs in his analysis stimulates the rise to power of the local armed groups in order to establish a new social order in the predominant chaos. They build a local order, exerted by armed coercion, based on the provision of services in exchange for food, water supply, physical security. He refers to this social mechanism as a new Dark Age.

This film offers the possibility of discussing the remote origin of nuclear war and environmental disaster that destroyed the world of Eli. It was the result of human perversion that distorted the reception of the sacred texts. When Eli leads him the last existing version of the King James Bible at an inner command, the film suggests that God, in order to rebuild the world, determined that the ones who heard his call would have to bring all humankind sacred texts to a safe place of refuge. There these contents would be stored and would lose their lethality.

In the second section, this paper analyzes the literary references used to enlighten subject's behalf, hypotheses, and the research design. In the third section, this paper discusses the construction of identity by the survivors taking into account that the environment of Eli's Apocalypse is a revolutionary situation arising from the end of the cycle of the human king age, in the form of human history. Capitalism as a reification and goods producing process has reached the edge of its contradictions, yielding zero production, and a zero mark of use. In the fourth section, it has closed its activities as a reflective process in Eli's Apocalypse, as if the modernization insofar as it waded its way to the furthest of the its possibilities, would menace the very basis of the industrial society that built itself (Beck, 1995). The anarchic revolution projected in the film brings out a society devoid of social standards of conduct where negotiation is replaced by violence. The fifth section will analyze the construction of identity in a crisis-based and post-apocalyptic world. In the everyday life of this world, the identities of young survivors should not be recreated based either on the absence of history, in the ruined lifeless landscape, or out of the scarcity of resources and risk, with a permanent present time. In the desert, which is the main scenery of the film, it's written as “one loses one's identity" (Rutherford, 1998).

In the account of the analysis proposal, this paper employs a strong referential framework composed of high quality theoretical authors of the field. Aiming to analyze the memory theme, this paper uses the classic work of Ricoeur (2000), for whom, memory is a socially constructed artifact and the narrator, in order to regain his/her memory, becomes a center of fictional consciousness. Eli is depicted as an "epic person". If Eli's narrative begins in anacronia, soon he manages to recover fragments of time. It begins with the chaos, then the apocalypse happens, he tries to go back to explain the present chaos in his narration. The world narrated by Eli is a world where he exists as a character within its own narrative. However, the theoretical apparatus adopted suggests that the process of engendering identities in a timeless and scarce world is performed by the recovery of the memory and the history mediated by the narrative. Halbwachs (1997), for whom the memory is a collective construction, said that it is a reminder of the deep need of one another. For the experience of belonging to a human group, it makes personal memory an acquisition made on the memory and on the knowledge received from others. Halbwachs considered that, therefore, in this light, people will never be alone. In this post-apocalyptic world, there is a break. Since people are lonely and living by themselves, they may not have the memory that comes from a no longer existing social life. In the film, there are lots of wrecked monuments, which for Halbwachs depict the collection of places visited in common. But in the post-apocalyptic world, the significance of these places disappeared and its image is changing. 
According to Hall, Held, and McGrew (1992), the debate on the concept of identity is too complex and extensive, thus being, the work falls under extremely precarious bases. Meanwhile, analyzing postmodern society as a high-risk society, where people live under a "manufactured" uncertainty on every side, Giddens (2002) saw the possibility of a catastrophe. For Halbwachs, memory is an active and social process which should not to be confused with a simple reminder. The film discusses the need for an identity that does not exist: The only one that held it was the eldest for he was able to cling to fragments of time and history. The new ones and Solara will have to build a new society where the collective wisdom and memory can be transmitted by establishing the reliability of the institutions. Yet, as Bauman (2004) noted, it confers the ability to take risks, make choices, and have the triple confidence in themselves, others, and society.

In the conclusion, this paper observes that Eli is, as suggested by Beck (1995), a leader seeking his own identity summed up not by what he knows, or he is aware of his ability to narrate, but in search of what he knows, that is, "not knowledge", that is the key reflection, i.e., the change in their post-apocalyptic world. He believes that this will be revealed when delivering the west the book that he carries. This will redefine the structures of life in a society where the struggle for desired goods competes with the new reality - the post-apocalyptic, that is a risky society. As Rossi (1955) wrote, the fear before an uncontrollable world, slavery of contemporary man, the responsibility of the machinery sacrilegious violation of unspoilt nature, all these varied themes mind mixed together become another "average faith" intellectuals of the West.

\section{Survival: Fate and Destiny}

The film hero, Eli, played by Denzel Washington, makes use of nifty survival techniques in a hostile environment. He brings water, weapons and a Bible with him in the King James version, in which an inner voice entrusted him to take to the west. A survivor in the conception of Émile Benveniste, his ambiguous identity is of an ancient and a modern era; in Greek, superstes is the individual who is held hostage by a repressed old order by religion. It is also confusing that the definition of superstition, located between superstes as a survivor and witness and superstitious as a soothsayer (Benveniste, 1969). Ruled by a notion of fate and destiny, echoing the religious revival, its narration in a high-risk environment allows for the return of the repressed (Giddens, 2002). Eli integrates the "exodus generation" whose identity is divided between a past and a history they knew and the timeless present, with no way out (Giddens, 2002). The survivors suffered trauma and bear collective wounds resulting from the object lost, without the possibility of having worn mourning attire (Ricoeur, 2000). Eli is blind, although endowed with refined hearing and smell, making his character talk like the Japanese film Zaitochi (Kitano, 2003). In it, a blind samurai, endowed with exceptional sensory capability, eliminates his adversaries in a violent and unfair Japan.

The identity of characters like Eli, Carnegie, and Claudia, survivors of a previous time/world, plays an essential pedagogical role in the future of the surviving generation who lived the ante-bellum, because their identity is based on history and memory. Carnegie, for example, an expert of the local territory before the Apocalypse, knows where to find the hidden water. He establishes the primal violence and celebrates it for his personal glory and the humiliation of others. Perhaps, therefore, the Bible is essential to him containing a legitimizing speech of original violence.

The identity of the young survivors does not consolidate due to the gap represented by the loss of cultural traditions and sociability networks. Like Solara, born after the Apocalypse, her existence is marked by the ambiguity represented by the nonexistence of the categories of history, space, and future in one unique 
presenteeism (Ricoeur, 2000). She travels through the parched landscape littered with monuments from the past: interrupted viaducts, abandoned vehicles, the golden gate destroyed, and an useless nuclear power plant. For Solara, these will be natural disasters whilst Eli sees them endowed with the power of representation of the past when financial capitalism reached its apex, modifying the territory through costly and complex projects such as the construction of railways and highways, privatization of natural resources, development of suburbs (Jameson, 2009). For Pomyan, monument in Latin is monere, to remind, although, in a printed or written document, it is based on docere, to instruct and to teach.

\section{No Currency in the Apocalipse, but Still Merchandise}

Eli stays in a house overnight, taking possession of a corpse's boots. After a brief hygiene showing his burnt back, he cooks the cat he killed and keeps the feline's fat; he offers a piece of meat to a rat attracted to the smell of food. In the apocalyptic high-risk society, mediation is successful due to the mandatory violence of the almighty group against one individual who is alone and vulnerable (Giddens, 2002). On a ruined road crossing a woman lurks, as a lure set by a group of vicious robbers, their odour body Eli can smell from afar. After talking to them, the hero kills them all in a sophisticated choreography.

Eli then arrives at a city ruled by Carnegie, who lives in a building which is a mixture of an Art-Deco cinema, the Orpheum. There is a saloon and a food court, along with his blind wife, Claudia (Jennifer Beals) and his stepdaughter Solara (Mila Kunis). In a workshop that is owned by a character called the Engineer, Eli tries to recharge the battery of his walkman. The Engineer asks what he has to offer. Eli puts on the counter objects it has in his backpack and that were collected along the way he has done. Inter alia, products such as lighter and cat oil, are claimed to be good to avoid sunburn. Held exchange, the walkman is reloaded.

In the Orpheum, residence of Carnegie, Eli gets water. Again bartering is practiced and when Eli puts objects on the counter, the attendant chooses them according to the high price charged on clean water. He calls Solara to fill the Eli's canteen and give her some kind of card that is submitted to the server that controls water supply.

The looters who are on Carnegie's payroll, present him with books that he despises, because what he really wants is a Bible. When Eli acquires water in the cinema, he is provoked by a looter and ends up almost killing them all, only stopping the massacre at Solara's request. Carnegie, impressed with the stranger, invites him to join the group, thus inverting the relation of modernity: "the future belongs to us, the elders". Carnegie presents himself as a post-apocalyptic high class member, which, according to Marx, can turn him into a thinker, as, Carnegie is for us a producer of ideas, ruling the production, regulating the distribution of the ideas of his time (Marx \& Engels, 2007).

The memory of the past and the disappearance of knowledgeable records allow the elders to recommence the supremacy gained at the beginning of time. As Gasset (1961) highlighted that, man has no nature, it has history and the catastrophe that interrupted it did not allow what Ricoeur (2000) calls a "generational sequence" to happen and that ensures a transition among different eras of history. Eli stays overnight at the invitation of Carnegie, who shrewdly sends him food and water and Solara to seduce the traveler. Before they share a meal together, Eli prays in an unknown gesture to the young girl who is fascinated by the gesture that comes from the world before the war. In the morning, Solara is forced to confirm that Eli has a Bible. When Carnegie tries to stop him, Eli seems invulnerable to weapons, slaughtering a large number of henchmen and wounding Carnegie. On resuming his westward path, he is stealthily followed by Solara, who was sent by Claudia. Eli 
repels her. However, given the fragility of the young woman, he begins to teach her by narration, contributing to the construction of her identity through a rescue operation of memory and history.

\section{Memory, History, Narration}

The narration, Halbwachs (1997) considered that, in order for people to remember, people need the information received from others. The national space where the narrator resided and which he was a part of a theatre filled with meanings. When the narrator evokes them, he is obliged to employ the memory of others who are a mandatory source. He carries historical baggage with him in the form of memories, which can be amplified by reading or conversation. For Ricoeur, in being "himself" he is "another"; the "himself" claims an ambivalent identity that carries the "I" and the "other". The author of the action assumes the reporting role like someone who performs a gesture that contextualizes the action. Understanding itself is an interpretation which finds a privileged mediation in the narrative. The individual understands himself narrating his own experiences, describing human action as a text. To Gagnebin, Paula, and Sperber (2011), one must not let the past forgotten as an issue that doesn't need to be an epic or heroic text reporting the past under a humble and less triumphant aspect. For Ricoeur, the narrating unit of life means that the person whilst being understood as a narrative character, its identity interacts with the story which is being told.

Solara's social framework, dominated by Carnegie, has no social recall or sharing. As a narrator, Eli makes his memory a permanent gift; as Halbwachs teaches people, the notion of history is magnified by conversation and reading. Meanwhile, willing to take revenge, Carnegie and his henchmen pursue them both, now hiding in a wooden house inhabited by an elderly couple. When they realize that their hosts are cannibals, they try to leave. The house is attacked by Carnegie who takes hold of Solara and threatens to kill her in exchange for the Bible. Eli hands him the book, determined to read it no longer, but to follow the teachings of the book. Carnegie ends up taking him down with a shot in the stomach. After a short fight, Solara manages to escape from her stepfather and later finds Eli.

\section{Conclusions}

They travel together to a ghostly San Francisco, where they find a community dedicated to recovering lost culture on Alcatraz Island. Before dying due to an injury from a shot fired by Carnegie, the narrative is interrupted, according to Ricoeur (1984), before the hero has reached the narrator, it is inconceivable that they could write together this way. For its leader, Eli recites the Bible, word for word, which is then printed and laid on a shelf next to other sacred books of Humanity. This almost furtive scene (and it is in slow motion, almost frame by frame) recalls the Japanese feature film of Oshima (1976), In the Realm of the Senses. It is set in 1936, the year when there was a bloody attempted military coup by the radical right in Tokyo. The film chronicles the intense extreme sexual passion between two lovers only sated by death. They briefly split and the man, taken by lust, rapes one of the brothel's guests, practising anal intercourse. As he undresses the colorful kimonos from the woman, it can be noted that the last of them boasts the pattern of the Japanese imperial flag, the flag of war.

In his office, a dying Carnegie begs Claudia to read the Bible which is printed in Braille. She refuses, claiming to have forgotten how to do so. Eli dies on Alcatraz while Solara decides to leave, placing her friend's sharp sword in her back-pack, in a mis-en-scéne which recalls Azumi by Kitamura (2003), where the samurai heroine carries her deadly weapon on her back. 
When the leader invites Solara to stay, she refuses. When she is asked where she is headed, she does not hesitate with the word "home". Solara is then the one who returns home, carrying the experiences to narrate. The young woman envisions a future designed in the familiar environment that acquires symbolic consistency when it recovers, through the memory, a sense of history. Where is home? The home, as answered by the American singer Eartha Kitt, mentioned by Ruherford, "is with me", and "home is where we speak from" (Rutherford,1998). Like the final words of the Wizard of Oz (Fleming, 1939), home means Claudia, the owner of the memory that will allow Solara to recompose her identity that, in a revolutionary and apocalyptic time, persists, as Kobena Mercer wrote, as a multifaceted and polysemic term. It only becomes an issue when a future is glimpsed in a time of crisis (Mercer, 1990).

\section{References}

Amim, S. (2011). Ending the crisis of capitalism or ending capitalism? Oxford: Pambazuka Press.

Bakker, K. (2010). Privatizing water: Governance failure and the world urban water crisis. Ithaka: Cornell University Press.

Bauman, Z. (2004). Identity: Conversations with Benedetto Vechi. Cambrigge: Polity Press.

Beck, U. (1995). Reflexive modernization. Politics, tradition and Aesthetics in the modern social order. Stanford: Stanford University Press.

Benveniste, É. (1969). Le vocabulaire des instituitions indo-européennes. 2. poivoir,droit,religion. Paris: Les Éditions De Minuit.

Chew, S. C. (2008). Ecological futures: What history can teach us (Trilogy on world ecological degradation). Plymouth: Altamira Press .

Fleming, V. (Director). (1939) Wizard of $O z$ [Moction picture] United States, Metro Goldwin-Mayer.

Gagnebin, J. M., Paula, A. C., \& Sperber, S. F. (2011). The memory, the history, and the forgiveness. Retrieved from http://www.dominio public.gov.br./download/texto/gd000047.pdf

Gasset, J. O. (1961). History as a system and other essays. New York: WWW Norton \& Company.

Giddens, A. (2002). Self and society in the late modern age. Oxford: Polity Press.

Halbwachs, M. (1997). La mémoire collective. Paris: Albin Michel.

Hall, S., Held, D., \& McGrew, T. (1992). The question of cultural identity, modernity and its futures. London: Politic Press/Open University Press.

Hitchcock, M. (2012). The Middle East is burinng. Eugene: Harvest House Publishers.

Hugues, Albert. \& Hugues, Allen. (Director). (2010) The book of Eli [Motion picture]. United States: Sony Pictures.

Jameson, F. (2009). The cultural turn (Selected writings on the Postmodern, 1983-1998, London, New York, Verso).

Kitamura, R. (Drector). (2003). Azumi [Moction picture]. Japan: Toho.

Kitano, T. (Director). ( 2003 ). Zaitochi [Moction picture]. Japan: Bandai Visual.

Marx, K., \& Engels, F. (2007). A ideologia alemã. Rio de Janeiro: Eitora Boitempo.

Mercer, K. (1990). Welcome to the jungle: Identity and diversity in postmodern politics. In J. Rutherford (Ed.), Identity, Community, Culture, Difference. London: Lawrence \& Wishart Limited.

Oshima, N. (Director). (1976). In the Realm of the Senses [Moction picture]. Japan: Keichi Uraoka.

Ricoeur, P. ( 2000). La mémoire, l'histoire, l'oubli. Paris: Éditions Du Seuil.

Ricoeur, P. (1984). Temps et récit 2. La configuration dans le récit de fiction. Paris: Édtions du Seuil.

Rossi, P. (1995). Naufragisenzaspettatori. L'ideadi progresso. Bologna: SocietàEditrice Il Mulino.

Rutherford, J. (1998). Identity, community, culture, difference. London: Lawrence \& Wishart Limited. 